\title{
Władysław Stojak - pierwszy przewodniczący NSZZ "Solidarność" w Miastku. Prosty człowiek na trudne czasy
}

Łukasz Szkwarek | Wydział Historyczny, Uniwersytet Gdański

\section{Streszczenie}

Słowa kluczowe:

"Solidarność",

Miastko,

Strzebielinek Władysław Stojak

"Solidarity",

Miastko,

Strzebielinek,

Władysław Stojak
Celem artykułu jest przedstawienie dziejów i specyfiki działania NSZZ „Solidarność" w latach 1980-1981 w małym mieście Miastko. Pod uwagę został wzięty Władysław Stojak, przewodniczący Międzyzakładowej Komisji Koordynacyjnej "Solidarność" w Miastku w latach 1980-1981. Na jego przykładzie można zaobserwować wzajemne przenikanie się członków "S" i działaczy PZPR. Wynika to z dość silnego upartyjnienia gminy Miastko. Celem artykułu jest także ukazanie sylwetki Władysława Stojaka.

\section{Władysław Stojak - the first leader of the Independent Self-governing Labour Union "Solidarity" in Miastko. A simple man for hard times}

Abstract

The aim of the article is to present the history and specificity of the Independent Self-governing Labour Union "Solidarity" activities in a small Polish town Miastko, in the years 1980-1981. Interactions between the " $S$ " members and the Polish United Workers' Party (PUWP) activists can be observed on the example of Władysław Stojak, the chairman of the Interagency Coordination Committee "Solidarity" in Miastko between 1980 and 1981. This is due to the significant number of PUWP members in Miastko at the time. Another aim of the article is to present the silhouette of Wladyslaw Stojak. 
Władysław Stojak urodził się 10 lutego 1945 roku w miejscowości Sidra pod Sokółką na Podlasiu. W tym samym roku jego rodzina przeniosła się do Szczecinka. W 1950 w wyniku epidemii polio zmarła jego siostra, natomiast mały Władysław doznał porażenia stopy. To schorzenie spowodowało problemy z chodzeniem. W 1957 roku z powodu pobytu rodziców w szpitalu dzieci Stojaków trafiły do pogotowia opiekuńczego w Koszalinie, a następnie do domu dziecka w Wierzchowie pod Człuchowem. Planowany trzymiesięczny pobyt został przedłużony do czterech lat z powodu rozstania rodziców. Władysław Stojak z rodzeństwem przebywał w domu dziecka do 1961 roku (Stojak 1982b; Stojak 2014a; Stojak 2014b).

W 1961 roku zaczął uczęszczać do Zasadniczej Szkoły Zawodowej w Słupsku, w klasie o specjalności krawiectwo męskie. Mieszkał w wynajmowanym mieszkaniu, opłacanym przez matkę. Po dwóch latach musiał przerwać naukę, gdyż jego matce zabrakło pieniędzy na utrzymanie stancji. W tym samym czasie rozpoczęła swoją działalność Fabryka Rękawiczek i Odzieży Skórzanej w Miastku. Z dniem 13 listopada 1963 Władysław Stojak rozpoczął pracę jako krojczy w tejże fabryce. W sierpniu 1964 roku wziął ślub z Elżbietą Grabowską, a w rok później urodził im się syn - Jarosław (Stojak 1982b; Stojak 2014a).

Do Polskiej Zjednoczonej Partii Robotniczej (Protokół z III Konferencji... 1981) wstąpił w 1964 roku. Jak wspominał po latach, głównym motywem była chęć awansu społecznego dla dziewiętnastoletniego, nie w pełni wykwalifikowanego robotnika. Uważał, że jako członek partii będzie miał większy wpływ na sprawy społeczne. W 1981 roku, podczas I Walnego Zebrania Delegatów, mówił: „Wierzyłem w partię, jak i w to, że partia jest w stanie przyjść z pomocą ludziom pokrzywdzonym przez los. Sam się tak właśnie określam, byłem przecież wychowankiem domu dziecka. Wstąpiłem do PZPR, aby móc podjąć działalność dla polepszenia warunków życia sobie i innym, którzy tego oczekiwali" (Walne Zebranie Delegatów NSZZ... 1981).

Według własnej relacji Władysław Stojak w 1970 roku po masakrze grudniowej próbował złożyć legitymację partyjną, zmienił jednak zdanie po przejęciu władzy przez Edwarda Gierka. Na ten czas przypada okres jego zaangażowania w działalność partyjną.

W styczniu 1975 roku został wybrany członkiem Komisji Kontroli Partyjnej przy Komitecie Powiatowym PZPR w Miastku. Pełnił także funkcję przewodniczącego Oddziałowej Organizacji Partyjnej w fabryce (Protokół z pierwszego plenarnego posiedzenia Komitetu Powiatowego... 1975; Kontrwywiadowcza charakterystyka... 1984; Grymbowski 2013; Stojak 2014a)'. Został odznaczony Brązowym Krzyżem Zasługi (14 lipca 1978 roku) oraz Brązową i Srebrną Odznaką Brygady Pracy Socjalistycznej, co świadczy o tym, że był uważany za przodownika pracy. Jak można przeczytać w opinii kapitana Krzysztofa Helmana, „o jego lojalności [Stojaka - przyp. red.] wobec Partii

' Według relacji jednego ze świadków podpis Stojaka miał widnieć na naganach partyjnych za udział za uchylanie się od udziału w masówkach potępiających wydarzenia radomskie 1976 roku, kwestia ta wymaga dokładniejszego zbadania. 
[kontekst tekstu wskazuje, że chodziło o sytuację przed roku 1980 - przyp. red.] może świadczyć fakt, iż usunął on również ze swojego mieszkania wizerunki kultu religijnego" (Stojak 1982a; Helman 1984)². Od jesieni 1977 roku przestał uczestniczyć w pracach Komisji Kontroli Partyjnej. W następnym roku zrezygnował z funkcji przewodniczącego OOP we FRiOS (Protokół z przeprowadzonej kontroli... 1977; Walne Zebranie Delegatów NSZZ... 1981; Stojak 2014b)3. Przyczynami wycofania się z pełnienia funkcji partyjnych było narastające rozczarowanie polityką partii w okresie kryzysu gospodarczego, zniechęcenie masówkami po Radomiu '76. Istotne były też sprawy prywatne. Stojak przez kilka lat budował dom przy ul. Mickiewicza, na który zaciągnął kredyt. Jak sam wspominał, miał problem z uzyskaniem materiałów na budowę domu, a następnie dość długo spłacał kolejne raty kredytu, wzrastające z powodu inflacji (Stojak 1982b; Król 2013; Stojak 2014a)4.

W okresie Sierpnia ' 80 strajki z zakładów pracy na Wybrzeżu rozszerzyły się na inne zakłady pracy w województwie słupskim. Od 22 sierpnia 1980 roku miasteckie zakłady pracy wysunęły wiele postulatów ekonomicznych i społecznych (Informacja dotycząca wniosków i postulatów... 1980). Dość późno, bo 28 sierpnia, w FRiOS zaczął się niewielki protest jednego oddziału krajalni kierowanego przez Henryka Brzostkowskiego. Doszło do spotkania z I sekretarzem lokalnego Komitetu Miejsko-Gminnego PZPR Stanisławem Zelkiem, który zaprosił na ogólne zebranie wszystkich strajkujących z gminy Miastko w Powszechnej Spółdzielni Spożywczej. Delegatem na to spotkanie wybrano Władysława Stojaka, który poszedł na nie z Haliną Moskal (Heldt 2013; Stojak 2014; Rodź 2015; Brzostowski 2015).

Prawdopodobnie pod koniec sierpnia 1980 roku doszło do ogólnego zebrania w PSS. Tylko dwa zakłady pracy wnioskowały o powstanie niezależnych związków zawodowych (Państwowa Komunikacja Samochodowa i FRiOS - por. Informacja dotycząca wniosków i postulatów... 1980). Po podpisaniu porozumień sierpniowych dotarła do Miastka wiadomość o tworzącym się ruchu "Solidarności” w Słupsku. Miejscowe zakłady pracy rozpoczęły oddolne tworzenie nowych związków zawodowych. W październiku 1980 roku Władysław Stojak został wytypowany jako delegat FRiOS na spotkanie z władzami Wojewódzkiego Komitetu Założycielskiego NSZZ „Solidarność". Wraz z nim do Słupska pojechał także pracownik POLAM Mieczysław Trzebiatowski (Hałagida 2010a; Stojak 2014a)5. Wzięli udział w spotkaniu delegatów w Słupsku,

\footnotetext{
${ }^{2}$ Brak jest jednak bliższych informacji, czy chodziło o wcześniejsze mieszkanie przy ul. Młyńskiej, czy też o dom przy ul. Mickiewicza, w którym bohater artykułu mieszkał od 1978 roku.

${ }^{3}$ W liście tym bohater artykułu twierdzi, że zrezygnował z udziału w obradach KKP "po pierwszej takiej kontroli, gdzie członek PZPR-robotnik przywłaszczył [...] niewielką ilość kartofli czy zboża".

${ }^{4}$ Jak wynika z opinii kapitana K. Helmana, Stojak „pracował na dwóch zmianach, by więcej zarobić".

${ }^{5}$ Jak wspominał W. Stojak, „Pojechałem na to zebranie, kilkudziesięciu siedziało za stołami, było ciemno na tej sali, była ogromna dyskusja, że coś powinniśmy zrobić. Następnie Kazik Duda, późniejszy przewodniczący, pyta się o regiony, kto jest z Człuchowa, Bytowa, z Miastka. Więc mówię, że ja jestem z Miastka, więc mówi do mnie: «Musisz zrobić w ten sposób, że jak są te stare związki zawodowe, to musisz znaleźć człowieka na zakładzie, żeby puścił listę, kto jest za związkami ,Solidarności'»". Udział M. Trzebiatowskiego w wyjeździe do Słupska potwierdza relacja S. Śledzia (2015) z 10 stycznia. Istnieje jednak możliwość, że relacja Stojaka dotyczy któregoś zebrania z września.
} 
podczas którego otrzymali pełnomocnictwa do tworzenia nowych związków i oficjalnego założenia międzyzakładowych struktur (Teleks nr 185 dot. sytuacji... 1980)6.

Tymczasową siedzibą ruchu solidarnościowego była Słupska Fabryka Mebli. Dnia 23 października 1980 powstał Międzyzakładowy Komitet Założycielski NSZZ "Solidarność" w Miastku, przekształcony później w Międzyzakładową Komisję Koordynacyjną. Władysław Stojak został wybrany tymczasowym przewodniczącym. Jak się może wydawać, wybrano go z powodu agitacji na rzecz tworzenia nowych związków oraz z powodu wyrażenia chęci pójścia na bezpłatny urlop w pracy. Jego zastępami zostali: Mieczysław Trzebiatowski, Józef Kłobuszyński, Antoni Otoka oraz Józef Puszakowski (Walne Zebranie Delegatów NSZZ... 1981). Wybór Stojaka spotkał się z zaskoczeniem miasteckiego SB, które w swojej kontrwywiadowczej charakterystyce terenu Rejonowego Urzędu Spraw Wewnętrznych z 1984 roku zapisało: „do października 1980 roku jako wieloletni pracownik FRiOS cieszył się dobrą opinią" (Kontrwywiadowcza charakterystyka... 1984). Siedzibą miasteckiej "Solidarności” od 10 listopada 1980 roku był lokal przy ulicy Kazimierza Wielkiego 7.

W związku z wyborem Stojak został oddelegowany na bezpłatny urlop. Od czerwca 1981 roku jego pensja wynosiła 10000 zł miesięcznie (Karwowski 1980; Walne Zebranie Delegatów NSZZ... 1981). Jako szef miasteckiej "S" stał na czele Biura Interwencyjnego, przyjmując skargi od interesantów oraz dokonując kontroli zaopatrzenia w sklepach. Przeprowadził zbiórkę pieniędzy na rzecz pomnika Poległych Stoczniowców. W tym czasie, jesienią 1980 roku, stosunki na linii PZPR-_,Solidarność" układały się pozytywnie, gdyż polityka centralnych władz partyjnych polegała wówczas na zachęcaniu do wstępowania do Solidarności (chciano w ten sposób utrzymać kontrolę nad związkiem - por. Kamiński 2002: 31). Należy podkreślić, że teren gminy Miastko był terenem dość silnie upartyjnionym - w lipcu 1980 roku w Miastku do PZPR należało 2182 członków i kandydatów. Miastecka organizacja partyjna pod względem liczebności działaczy znajdowała się na trzecim miejscu w województwie słupskim, zaraz za Komitetem Miejskim w Lęborku (2827) i Komitetem Miejskim w Słupsku (11 188). Tak duże upartyjnienie spowodowało więc w latach 1980-1981 wzajemne przenikanie się członkostwa w PZPR i przynależności do "Solidarności". Dlatego też, podobnie jak w sąsiednim Bytowie, stosunki między rządzącą partią a niezależnymi związkami układały się pozytywnie. Odbywały się spotkania przedstawicieli MKK z władzami miasta poświęcone poprawie sytuacji w miejscowości (Okoniewska 1998: 540). Sam Stojak znał dość dobrze I sekretarza PZPR Stanisława Zelka, który był jego wychowawcą w domu dziecka w Wierzchowie w latach 1959-1960.

Już 1 grudnia 1980 roku słupskie SB umieściło Władysława Stojaka na liście osób przewidzianych do izolacji. Przyczyną tej decyzji było „krytykowanie władz województwa i miasta, negatywnie wypowiadał się o partii". Jak pisano, "stał się osobą negującą i atakującą wszystko, co dotychczas osiągnięto". Funkcjonariusze bezpieki zwrócili

${ }^{6}$ Prawdopodobnie Stojak i Trzebiatowski wzięli udział w zebraniu delegatów w Słupsku 18 października 1980 roku. 
uwagę na zdolności przywódcze przewodniczącego MKK (Arkusz ewidencyjny... 1980; Cenckiewicz 2008: 437)․ Należy zauważyć, że w arkuszu podkreślano wyłącznie negatywne wypowiedzi Stojaka na temat partii. Jak wynika jednak z protokołów komisji zakładowych, jesienią 1980 roku miastecka "Solidarność" starała się unikać publicznej krytyki partii (Protokół z narady z siostrami pogotowia... 1980). Prawdopodobnie umieszczenie przewodniczącego na tej liście było spowodowaną pośrednią krytyką nadużyć władzy. W dniu 10 grudnia Stojak polecił komisji zakładowej w Rejonowym Przedsiębiorstwie Gospodarki Komunalnej i Mieszkaniowej udokumentowanie remontów mieszkań u sekretarzy komitetu miejsko-gminnego i komendanta MO, Zbigniewa Zaleskiego (Stojak 1980). Po podliczeniu rachunków okazało się, że komendant wykonał remont swojego mieszkania na kwotę 190877 zł. Według związkowców zostało to pokryte przez RPGKiM, dzięki czemu Zaleski nie zapłacił za remont (Gargol 1981). Podobne działania wobec mieszkania po I sekretarzu Komitetu Powiatowego PZPR w latach 1972-1975 - Tadeuszu Pałczyńskim - podjęła utworzona w dniu 24 kwietnia komisja przy MKK w składzie: Władysław Stojak, Józef Sobolewski, Józef Puszakowski i Stanisław Łęczycki (Pismo do Zarządu Gospodarki Terenowej.. . 1981). Wkrótce potem działacze tejże komisji skarżyli się na poczucie zagrożenia ze strony funkcjonariuszy $\mathrm{MO}$, twierdząc, że w prywatnych rozmowach są zastraszani i nakłaniani do zaprzestania zajmowania się tą sprawą. W sierpniu 1981 roku zarząd miasteckiego podregionu zagroził przeprowadzeniem strajku przez wszystkie miasteckie komisje zakładowe w dniu 17 sierpnia (Skarga do NIK 1981). Prawdopodobnie sprawa została załagodzona poprzez rozmowy przedstawicieli zarządu regionu z prokuratorem wojewódzkim oraz delegatem NIK z Koszalina.

W Słupsku Stojak nawiązał bliższe kontakty z niewygodnym dla władz przewodniczącym Międzyzakładowego Komitetu Założycielskiego NSZZ "Solidarność" w tym mieście - Kazimierzem Dudą (Hałagida 2016). W lutym 1981 roku przewodniczący miasteckiej „S” został zaproszony na rozmowę z szefem Wojewódzkiej Komisji Kontroli Partyjnej, Klemensem Cieślakiem, który zaproponował mu pieniądze na spłatę kredytu w wysokości 150 tys. zł w zamian za nakłonienie innych do usunięcia z funkcji przewodniczącego Dudy. Stojak odmówił przyjęcia tych pieniędzy, motywując, że zarabia 8 tys. zł. W dniu 12 marca 1981 roku podczas zebrania w słupskim MKZ ujawnił tę propozycję, stając w obronie Dudy, który został jednak odwołany z funkcji przewodniczącego (Informacje dotyczące zebrania... 1981; Hałagida 2011a: 64; Stojak 2014a). Słupskie SB za kolejne zadanie przyjęło sobie doprowadzenie do odwołania Stojaka ze stanowiska (Informacja operacyjna... 1981; Hałagida 2010b: 85) ${ }^{8}$.

W okresie tak zwanego kryzysu bydgoskiego (ostrego konfliktu między "Solidarnością" a PZPR z powodu pobicia trzech działaczy związku przez MO) ujawniły się także pierwsze podziały w miasteckim komitecie. Podczas dyżuru komitetu strajkowego w PKP doszło do konfliktu między przewodniczącym Stojakiem a działaczami

\footnotetext{
${ }^{7}$ W ramach akcji Klan zbierano sporzą dzano szczegółowe informacje na temat przywódców solidarnościowych ${ }^{8}$ Według relacji J. Sobolewskiego (2015) z 6 lipca roku miasteccy funkcjonariusze SB mieli określać Stojaka mianem Goebbelsa.
} 
"Solidarności" w PKP. Zdarzenie to nie ma potwierdzenia w dokumentach, występuje jednak w dwóch, niezależnych od siebie relacjach. Jak wspominał po latach przewodniczący komisji zakładowej w PKP Józef Medel,

W 1981 roku robiliśmy strajk w Miastku, w noclegowni, właśnie miedzy innymi razem z Ryśkiem Siekierkowskim. To był strajk głodowy [...]. To był taki ogólnopolski protest, związany właśnie między innymi z wydarzeniami w Bydgoszczy. Głównie jednak chodziło o kolej, mieliśmy pewne rzeczy do załatwienia. W Miastku były stare władze komunistyczne. Strajk głodowy był robiony w noclegowni, trwał pięć dni. [...] Pilnowali [milicjanci - przyp. autora] tego budynku, jakby to była nie wiadomo jaka twierdza. Szukali zaczepki, żeby ktoś z naszych coś przeskrobał ale nic takiego nie mogli znaleźć. [...] On [Stojak - przyp. autora] był moim zdaniem zbyt tolerancyjny, ugodowy wobec władz. Nieraz często chodziliśmy z Leszkiem na te zebrania, żądaliśmy bardziej radykalnych postępowań. Większość była jednak za umiarkowanym postępowaniem. Stojak był właśnie z tego umiarkowanego kręgu (Medel 2015).

Inaczej to zdarzenie pamięta Władysław Stojak:

Jak była sytuacja po tej Bydgoszczy, to miał być strajk ostrzegawczy w Polsce. Przyjechałem ze Słupska, chciałem wejść na kolej, powiedzieć im, żeby tu był spokój, żeby nic nie robili. Wchodzę, któryś miał tam urodziny, stół taki zastawiony, 20 butelek wódki, to wszystko było w tej komisji zakładowej. Mówię: „,Ludzie, co wy robicie. Jakby to w innym zakładzie było, ale to kolej, pracują tu kolejarze, którzy za chwilę pójdą gdzieś pracować, a wtedy wypadek gotowy. Zbieraj to, ja o tym nic nie chcę wiedzieć". Za moment przychodzi przewodniczący, mówi, że ma tutaj gościa, który przyjechał z Bydgoszczy, i tu będzie strajk dla poparcia, tutaj staną pociągi. Ja mówię: „Chłopie, tu nic nie stanie. Jeżeli ty coś zrobisz...”. Widzę, że wódka, towarzystwo nie w tym kierunku. Już na tyle byłem rozsądny, że wszędzie można było strajkować, tylko nie na kolei. Mówię: „Chcesz, ogłaszaj, ale będziesz za to odpowiedzialny" (Stojak 2014a).

W trakcie trwania strajku nie doszło jednak do zatrzymania pociągów. PKP należało do zakładów pracy, które miały być wyłączone z udziału w strajku ostrzegawczym i generalnym, stąd należy przypuszczać, że działacze "Solidarności" w PKP zadziałali zbyt radykalnie (Osiński, Rybarczyk, 2013a: 158; 2013b: 702) $)^{9}$. Sprawa ta była poruszana później na I Walnym Zebraniu Delegatów, kiedy to delegat PKP, Lech Janulewicz zarzucił brak dyżurów w siedzibie MKK na czas trwania strajku, powołując się prawdopodobnie na komunikat nr 1 KKP z 20 marca. Stojak tłumaczył się jednak późniejszymi otrzymanymi instrukcji od KKP z 24 marca, zgodnie z którymi siedziba MKS na czas strajku miała być przeniesiona do większych zakładów pracy (Walne Zebranie Delegatów NSZZ... 1981; Medel 2015). Nie rozstrzygając tej kwestii, był to na pewno jeden z pierwszych konfliktów prezydium MKK i przewodniczących komisji

${ }^{9}$ Chociaż według komunikatu Krajowej Komisji Strajkowej z 24 marca 1981 roku zakłady niebiorące udział bezpośrednio w strajku mogły wyrazić swoją solidarność ze strajkującymi w sposób uznany za stosowny. 
zakładowych z działaczami z PKP, tak zwanymi młodymi, zarzucającym starszym pracownikom zbytnią uległość wobec władz PZPR ${ }^{10}$.

Wiosną 1981 roku aktywną działalność w MKK rozpoczął dr Rajmund Rutkowski, który uzyskał dość duży wpływ na Stojaka (SB uważało go za duchowego ojca miasteckiej „Solidarności”). Wydaje się, że można jemu przypisać strategię postępowania wobec PZPR, jaką zastosowała miastecka "Solidarność". Rutkowski stanął na czele nowopowstałego Komitetu Obchodów Świąt 1, 3, 9 Maja (zwraca uwagę kompromisowa nazwa tego komitetu - por.: Wniosek Komitetu Obchodów... 1981; Protokół nr 9/81... 1981)1". Najważniejszym rezultatem działań tego komitetu było zorganizowanie mszy na Kaczym Dołku z 9 maja 1981 roku w intencji gen. Władysława Sikorskiego i wszystkich poległych w czasie drugiej wojny światowej. Po mszy odbył się przemarsz ulicami miasta. Przygotowana z rozmachem uroczystość okazała się dużym sukcesem propagandowym "Solidarności”, zwłaszcza że w 1981 roku w wielu miastach (także w Miastku) rezygnowano z pochodów pierwszomajowych (Protokół nr 9/81...). Sukces mszy spowodował jednak większe zainteresowanie SB osobą Władysława Stojaka (Walne Zebranie Delegatów NSZZ... 1981; TW Roman 1981) ${ }^{12}$.

Z powodu zbliżającego się IX Zjazdu PZPR w maju 1981 roku odbywały się wybory w miasteckim komitecie miejsko-gminnym. Stojaka wybrano delegatem na konferencję w dniu 28 maja 1981 roku. Wraz z przewodniczącym wybrano także działaczy "Solidarności": Rajmunda Rutkowskiego, Feliksa Harata oraz reprezentanta rolników indywidualnych Jana Żmudzkiego. Potwierdzona jest przynależność trzydziestu delegatów partyjnych do "Solidarności” (Protokół z III Konferencji... 1981; Pierwszy krok za nami 1981). Podczas tego zebrania doszło do zaprezentowania poglądów przez "Solidarność" w Miastku. Stojak i Harat odrzucili zaproponowane im stanowiska w komitecie miejsko-gminnym, zostali za to wybrani delegatami na wojewódzką konferencję. W trakcie zebrania doszło do otwartej krytyki partii w obecności sekretarza słupskiego Komitetu Wojewódzkiego PZPR Michała Piechockiego (Protokół z III Konferencji... 1981; Żmudzki 2014). Wydaje się, że udział w tej konferencji był inicjatywą Rajmunda Rutkowskiego, który w wywiadzie dla organu prasowego "Solidarności Słupskiej" stwierdził, że wierzył w odnowę partii po IX Zjeździe (Połeć 1981a). Prawdopodobnie związkowcy planowali zaprezentować swoje poglądy, zmienić partię oddolnie oraz mieli na celu przekonanie do siebie umiarkowanych działaczy partyjnych wbrew rozpoczynającej się od kryzysu bydgoskiego antysolidarnościowej

\footnotetext{
${ }^{10}$ Czołowymi działaczami tej frakcji byli: dwudziestodwuletni Józef Medel oraz dwudziestoczteroletni Lech Janulewicz. Prawdopodobnie przy pomyśle strajku głodowego sugerowali się pracownikami PKP z Wrocławia, którzy przeprowadzili analogiczny protest w październiku 1980 roku. Por. Sobolewski 2000: 18.

${ }^{11}$ Por. Tajne dokumenty Biura Politycznego Biura Politycznego. PZPR a "Solidarność", Londyn 1992, s. 350.

12 Jak można przeczytać w meldunku TW Romana, „Zwróciłem tu uwagę MKZ na osobę przewodniczącego MKK Miastko - Władysława Stojaka, który próbuje montować prowokacyjne elementy. Polecił między innymi Zastępcy Naczelnika Miasta, aby we mszy uczestniczyła kompania wojska, orkiestra wojskowa, FJN, organizacje społeczne i polityczne. Uzgodnił z księdzem Wituckim, iż ten wystąpi w czasie mszy naprzeciwko KM PZPR w mundurze generała i w asyście oficerów WP". Należy pamiętać o tym, że jest to meldunek tajnego współpracownika, który starał się przedstawić Stojaka w jak najgorszym świetle, przypisując mu nieprawdziwe informacje o rzekomych próbach nacisku na władze.
} 
propagandzie. Świadczy o tym wypowiedź Stojaka na spotkaniu z delegatami na wojewódzki zjazd partyjny, w której zaproponował zaproszenie delegacji z sowieckich zakładów pracy do Polski w celu "zapoznania ich z przebiegiem odnowy w Polsce i zapobieżeniu kolejnym publikacjom, szkalującym Polskę". Świadczy to o przemyślanym działaniu "S" miasteckiej, której działacze dawali wyraźny sygnał władzom partyjnym o braku antyradzieckich wystąpień ze strony związku (Teleks nr 177 1981).

W Słupsku w dniach 16-17 czerwca 1981 roku odbyła się Wojewódzka Konferencja Sprawozdawczo-Wyborcza, w której wzięli udział Stojak i Harat (Uchwała Komitetu Wojewódzkiego PZPR... 1981). Nie zachowały się z niej żadne protokoły. Potwierdzony jest fakt założenia znaczków solidarnościowych podczas obrad przez Stojaka i Harata (Połeć 1981b). Do nowych władz zostali wybrani jednak przedstawiciele partyjnego betonu, I sekretarzem KW został Mieczysław Wójcik, uważany za twardogłowego (Wyciąg z protokołu... 1981).

Dnia 27 czerwca 1981 roku odbył się w stołówce FRiOS I Walne Zebranie Delegatów Podregionu Miasteckiego. Jednym z celów tego zjazdu był wybór przewodniczącego zarządu podregionu. Podczas wyborów działacz "S" w PKP Lech Janulewicz zaatakował Stojaka, zarzucając, że działacze partyjni nie powinni wchodzić w skład prezydium. Oskarżył go również o nieuczestniczenie w obradach MKZ w Słupsku. Powrócił również do sprawy kryzysu bydgoskiego. Stojak odpierał zarzuty, powołując się na wytyczne Krajowej Komisji Porozumiewawczej. Wyraził również gotowość złożenia legitymacji partyjnej, ale tylko w razie pojawienia się oficjalnych zadań związku. $\mathrm{Na}$ razie jednak członkowie miasteckiej „Solidarności” „powinni współpracować z partią, broniąc jednocześnie spraw naszego związku" (Walne Zebranie Delegatów NSZZ... $1981)^{13}$. W trakcie posiedzenia miasteccy związkowcy zwrócili uwagę na fakt, że Stojak wykonuje za dużo samodzielnej pracy, wskutek czego należałoby go odciążyć od części biurowych obowiązków. Dość twardo w obronie Stojaka stanęli pozostali działacze "Solidarności" (Walne Zebranie Delegatów NSZZ... 1981).

W wyniku tajnego głosowania przewodniczącym NSZZ "Solidarność" Podregionu Miastko został wybrany przeważającą liczba głosów (42) Władysław Stojak. Na jego kontrkandydata Jana Terebeckiego głosowało szesnastu delegatów, zaś Janulewicz i Tadeusz Włodarski otrzymali odpowiednio po trzy i dwa głosy (Walne Zebranie Delegatów NSZZ... 1981). Wybór Stojaka był wotum zaufania dla jego działalności. Radość przewodniczącego zarządu podregionu musiała jeszcze zostać mocno zmącona tego samego dnia. Po zebraniu Stojak i Harat zostali zaczepieni przez byłego I sekretarza Komitetu Powiatowego w Miastku - Tadeusza Pałczyńskiego z żoną. Mieli oni zagrozić działaczom związku „połamaniem kości” (Skarga do NIK 1981) ${ }^{14}$.

\footnotetext{
${ }^{13}$ Lech Janulewicz w stanie wojennym został przyjęty do PZPR (Protokół nr 1/82... 1982).

${ }^{14} \mathrm{Http} / / /$ katalog.bip.ipn.gov.pl/showDetails.do?lastName $=\mathrm{pa} \% \mathrm{C} 5 \% 82 \mathrm{czy} \% \mathrm{C} 5 \% 84 \mathrm{ski} \& \mathrm{idx}=\& \mathrm{katalog} \mathrm{ld}=0 \& \mathrm{su}$ bpageKatalogld=1\&pageNo=1\&osobald=64336\& [dostęp: 17.5.2014]. Według informacji W. Stojaka Pałczyński miał być pod wpływem alkoholu.
} 
Zdarzenie to można traktować jako zapowiedź przyszłych zdarzeń, zostało też odebrane przez członków "Solidarności" jako groźba.

Po IX Zjeździe PZPR nastąpiła zmiana polityki władz centralnych Komitetu Centralnego wobec "Solidarności", przekreślająca szanse porozumienia się ze związkiem (Friszke 2014: 425). W związku z narastającym kryzysem gospodarczym postawa działaczy niezależnych związków zawodowych zaczęła się mocno radykalizować, coraz częściej uciekano się do gróźb strajku (Protokół z narady... 1981). Doszło także w tym czasie do zaniechania Stojaka. W proteście przeciwko atakom propagandowym w prasie na "Solidarność" - w dniach 19-20 sierpnia 1981 roku zorganizowano tak zwane dni bez prasy (strajk drukarzy i kolporterów prasy - por. Friszke 2014: 558). Miasteckie zakłady pracy miały się solidaryzować z drukarzami poprzez wywieszenie flagi. Akcję tę w miasteckim podregionie mieli koordynować Władysław Stojak i Henryk Biernacki (Hałagida 2010a: 49). Jak wynika z oświadczenia przewodniczącego Komisji Zakładowej w PBRol Czesława Bąka, tylko trzy zakłady wywiesiły flagę w tych dniach: FRiOS, PBRol oraz PTTK. Bąk zapowiedział, że nie będzie uczestniczył w takich akcjach, uznając je za niepotrzebne narażanie członków "Solidarności” na represje (Bąk 1981). Przyczyną fiaska tej akcji było najprawdopodobniej zbyt późne poinformowanie członków związku o tej sprawie. Jak twierdził w oświadczeniu, Bąk otrzymał informację telefoniczną przez Władysława Stojaka w dniu 18 sierpnia (dzień przed zaplanowaną akcją). Należy przypuszczać, że pozostałe miasteckie zakłady pracy były informowane o niej w podobny sposób przez Stojaka lub Biernackiego, przez co nie mogły się do niej przygotować. Zresztą w okresie narastającego kryzysu kwestię wolności prasy uznano za sprawę drugorzędną, tym bardziej że w samym Miastku nie było drukarni.

Punktem przełomowym w relacjach PZPR-,Solidarność" był I Krajowy Zjazd NSZZ "Solidarność". Zjazd ten spotkał się z negatywną reakcją Biura Polit. KC PZPR, które potępiło związek zawodowy w oświadczeniu Przeciwko awanturnictwu politycznemu i próbom niszczenia socjalistycznego państwa, oskarżając wprost działaczy związku o zdradę. Z inspiracji Władysława Stojaka załoga miasteckiego FRiOS wystosowała list otwarty wobec oświadczenia Biura Politycznego KC PZPR, krytykując je za "wypowiadanie się w imieniu całej klasy robotniczej”. Apel załogi FRiOS ukazał się w "Solidarności Słupskiej” oraz na tytułowej stronie ogólnopolskiego Tygodnika "Solidarność" (Kwiatkowski 1981, Teleks nr 291 1981, „Solidarność Słupska” 1981a, Tygodnik "Solidarność" 1981; Paczkowski 2002: 212; Kozłowski 2013: 44). Kolejnym krokiem była decyzja o złożeniu legitymacji partyjnej, co nastąpiło pod koniec września. Stojak wraz Rutkowskim udali się do komitetu PZPR, gdzie złożyli legitymacje partyjne. Nastąpiło wówczas ostateczne zerwanie władz miasteckiej „S" z partią (Protokół nr 19/81... 1981). W tym czasie funkcjonariusze słupskiej bezpieki określili Stojaka w jednej ze swoich notatek "krzykaczem, powiązanym z KSS KOR i KPN". Takimi sformułowaniami określano wówczas w oficjalnej propagandzie mocno zaangażowanych 
opozycjonistów (Notatka służbowa dot. Władysława Stojaka... 1981; Paczkowski 2002: 76; Hałagida 2011a: 110).

Jesień 1981 roku to okres otwartej wrogości między "Solidarnością" a władzami partyjnymi. Na początku października 1981 roku w Miastku pojawiły się plakaty ośmieszające "Solidarność" (plakat jednorocznego dziecka z zapałkami, stanowiący czytelną aluzję do niezależnego związku zawodowego - por. „Solidarność Słupska” 1981b). Sam Stojak zaczął spodziewać się aresztowania. W listopadzie 1981 roku jego postawa zaczęła się radykalizować, był przeciwny rozmowom z mediami oraz poszczególnych szeregowych pracowników z działaczami partyjnymi (TW Sąsiad 1981). W kilku niezależnych od siebie relacjach przewinął się wątek tworzenia tak zwanej drugiej linii działaczy "Solidarności”, którzy mieliby zastąpić przedstawicieli miasteckiego prezydium na wypadek aresztowania (Harat 2013; Heldt 2014; Butrym 2015; Ławer 2015; Śledź 2015; Medel 2015; Muchowski 2015). Nie da się, niestety, jednak udowodnić tego z racji braku istnienia archiwaliów. Jest kwestią dyskusyjną, czy lista ta została stworzona, czy tylko pozostała w planach. Plany takie świadczą jednak o napiętej sytuacji politycznej i związanych z nią konkretnych obawach. Podobne działania w skali kraju zauważa historyk Andrzej Paczkowski (Paczkowski: 2006: 38).

Ten stan napięcia skończył się wraz z wprowadzeniem stanu wojennego. W dniu 12 grudnia o godz. 23.30 do kierownika miasteckiego komisariatu MO przyszedł szyfrogram nakazujący aresztowanie Władysława Stojaka, Józefa Kłobuszyńskiego i Feliksa Harata (Szymak 1981) ${ }^{15}$. Bardzo szybko, bo już przed północą, milicjanci zawiadomili Stojaka, że musi się natychmiast udać na komisariat. Dopiero na komendzie MO został aresztowany. Pod wieczór przyjechała milicyjna nysa, która zabrała Stojaka, Harata i Kłobuszyńskiego (Rajmund Rutkowski został przywieziony 16 grudnia) do obozu internowania w Strzebielinku (Nakaz zatrzymania... 1981; Hałagida 2011b: 108; Stojak 2014a).

Władysław Stojak przebywał w obozie internowania w Strzebielinku od 13 grudnia 1981 do 12 lutego 1982 roku. Strzebielinek nie był uważany za obóz o szczególnie zaostrzonym rygorze (nie dochodziło tam do bić internowanych - por. Turek 2016). Jednak niepewność co do dalszych losów, rozłąka z rodziną oraz bezczynność dla internowanych okazała się dużym szokiem. W czasie pobytu na internowaniu, w dniu 28 grudnia 1981 roku, został zwolniony z pracy we FRiOS za "dwutygodniową nieobecność" (Stojak 1981) ${ }^{16}$. Ta decyzja spowodowała pogorszenie warunków życia rodziny Stojaka. Dość szybko zareagowali jednak pracownicy FRiOS, którzy z inicjatywy Mieczysława Grymbowskiego przeprowadzili zbiórkę pieniędzy na rzecz pomocy Elżbiecie Stojak i jej synowi (Grymbowski 2013; Stojak 2014a). W dniu 16 stycznia 1982 roku żona Stojaka napisała list do wojewody słupskiego z prośbą o interwencję w sprawie zwolnienia męża z internowania (Stojak 1982). Przygotowywana już pod koniec stycznia 1982 roku decyzja o zwolnieniu została jednak nieoczekiwanie wstrzymana.

\footnotetext{
${ }^{15}$ Oprócz wymienionych zatrzymani zostali także Rajmund Rutkowski, Jan Żmudzki i Roman Grochowski.

${ }^{16}$ Według relacji H. Brzostowskiego dyrektor B. Karwowski miał być naciskany przez władze stanu wojennego na zwolnienie Stojaka z pracy.
} 
Prawdopodobnie przyczyną była odmowa podpisania druku deklaracji o lojalności (jak twierdził Stojak w rozmowie z TW "Urbanem” Janem Tomczakiem, „złożył oświadczenie na piśmie według własnego uznania" - por. Gierałtowski 1982; Informacja operacyjna... 1982; Hałagida 2011b: 100). Podczas pobytu w ośrodku odosobnienia Stojak brał udział w protestach głodowych oraz w manifestacji w nocy z 12 na 13 stycznia 1982 roku (TW Urban 1982; Mur 1989: 45, 68; Cenckiewicz 2003: 537) ${ }^{17}$. Zachorował na zapalenie gardła. Jak wspominał, w lutym 1982 roku zaczął rozważać decyzję o wyjeździe z Polski. Jak wynika z relacji TW "Urbana”, Stojak pod koniec pobytu w obozie głośno rozpowiadał o dalszej działalności w konspiracji, co można interpretować jako chęć utwierdzenia władz w przekonaniu o potrzebie pozbycia się przeciwnika ustroju. W dniu 11 lutego 1982 roku Stojak został wezwany na rozmowę z kapitanem Andrzejem Pajchertem i podporucznikiem Jerzym Chumkiem, po czym następnego dnia został zwolniony z obozu internowania w Strzebielinku (Szymak 1982) ${ }^{18}$. Bohater artykułu przypuszcza także, że wpływ na decyzje o jego uwolnieniu mogła mieć także wizyta holenderskiego Czerwonego Krzyża w dniu 7 lutego 1982 roku (Mur 1989: 72, 75; Stan wojenny $w$ dokumentach władz PRL 2001: 138; Stojak 2014a).

Po powrocie do Miastka w wyniku procesu sądowego Stojak został przywrócony do pracy w czerwcu 1982, jednak na gorsze - w swoim odczuciu - stanowisko szwacza (Stojak 1982b; Stojak 2014; Brzostowski 2015). Był również wzywany na comiesięczne przesłuchania przez MO (podobnie jak pozostali internowani). Według własnej relacji miał się spotkać z lekceważącym stosunkiem części pracowników, co tylko przyspieszyło jego decyzję o wyjeździe. Wiadomo jednak, że utrzymywał kontakty z podziemną "Solidarnością," nie zdecydował się jednak na działalność konspiracyjną, tak jak działacze niezależnych związków zawodowych z Lęborka (Hałagida: 2012: 268). W słupskim numerze biuletynu OKO "Solidarność" z maja 1982 roku jego zwolnienie z pracy było ukazane jako przykład represji wobec związkowców. Jak można przeczytać w charakterystyce kapitana Helmana, Stojak "nie zmienił swych dawnych przekonań, aczkolwiek nie ujawnia ich na zewnątrz". Stwierdzono także, że jego decyzja o wyjeździe spowodowała konflikt w miasteckim związku. Był to jeden z celów akcji nakłaniającej działaczy "S" do wyjazdu z Polski (Stojak 1982b; „Solidarność". Biuletyn OKO... 1982; Paczkowski 2006: 106).

Już w marcu 1982 roku były przewodniczący miasteckiej "Solidarności” rozpoczął starania o wyjazd całej rodziny na pobyt stały do Stanów Zjednoczonych. Nie otrzymał jednak wizy od konsulatu USA (Stojak 1982b). W międzyczasie żona zrezygnowała z wyjazdu. Na zaproszenie brata Stojak chciał wraz z synem wyjechać na dwa tygodnie do Berlina Zachodniego, władze odmówiły jednak z obawy przed ewentualną możliwością samowolnego pozostania za granicą (Stojak 1983). Wkrótce jednak, po

\footnotetext{
${ }^{17}$ Potwierdzony jest źródłowo udział w głodówce w lutym 1982 roku. Według relacji W. Stojaka wziął on również udział w głodówce na wieść o masakrze w kopalni Wujek, o której wiedziano już w Strzebielinku 17 grudnia 1981 roku. Taka głodówka faktycznie odbywała się w dniach 19-22 grudnia 1981 roku w celi nr 6.

${ }^{18}$ Według kontrwywiadowczej charakterystyki Stojak podpisał deklarację lojalności.
} 
ukończeniu przez syna technikum, żona dała się przekonać do wyjazdu z Polski. Władze wydały paszporty na wszystkie strony świata, bez powrotu (wymeldowany na pobyt stały). Wcześniejszą decyzję o odmowie wydania paszportu można tłumaczyć chęcią kontrolowania przez władzę wyjazdów z Polski - w 1983 roku ewentualne pozostanie Stojaka za granicą byłoby odebrane jako ucieczka z PRL (Stola 2010: 153; Helman $\left.1984^{19}\right)$.

Dnia 29 maja 1984 roku Władysław Stojak wraz rodziną opuścił Polskę, wyjeżdżając do RFN. Przez dwa lata przebywał w Zagłębiu Saary, gdzie uczęszczał na kurs języka niemieckiego. W sierpniu 1986 roku znalazł pracę w firmie wyrobów skórzanych, w firmie F. Ehrenfrjedt Gmbh., gdzie pracował do 2008 roku. Obecnie jest na rencie. Po przemianach 1989 roku przyjeżdżał parę razy do Polski, ostatni raz był w 2008 roku. Jak sam podkreśla, nie żałuje decyzji o wyjeździe (Stojak 2014a).

Władysław Stojak to typ społecznika, który najpierw próbował działać w PZPR, potem $w$ "Solidarności". Jego doświadczenie, determinacja i odwaga była jednym z motorów napędowych miasteckiej "Solidarności”. Należy przyznać, że jego działania były dość mocno przemyślane, biorąc pod uwagę specyfikę silnie upartyjnionego terenu. Jego współpracownicy podczas I Walnego Zebrania Delegatów Podregionu Miasteckiego zarzucali mu, że wykonuje za dużo samodzielnej pracy, wskutek czego należałoby go odciążyć od części biurowych obowiązków (miało to wpływać na jakość jego pracy). Dlatego też w lipcu 1981 roku została zatrudniona w zarządzie podregionu sekretarka. Zebrane po latach relacje świadków w zdecydowanej większości wypowiadają się pozytywnie na temat Stojaka. Wiadomo jednak o konflikcie bohatera artykułu z grupą młodych kolejarzy z PKP. Z niewyjaśnionych do dziś powodów także pogorszyły się relacje Stojaka z jednym z jego zastępców - Mieczysławem Trzebiatowskim. Na tle innych przywódców solidarnościowych MKK i podregionów województwa słupskiego Stojak wyróżniał się przynależnością do PZPR. Z członkostwa w tej organizacji zrezygnował we wrześniu 1981 roku. Pobyt w ośrodku internowania sprawił, że zdecydował się na wyjazd do RFN. Po 1984 roku nie angażował się już w działalność polityczną.

\section{Literatura}

Arkusz ewidencyjny osoby, przeznaczonej do izolacji, 1980, Gdańsk: Instytut Pamięci Narodowej. Oddziałowe Biuro Udostępniania i Archiwizacji Dokumentów, 1.12., k. 59-61.

Bąk 1981, Pismo do W. Stojaka, k. 5004, Gdańsk: Archiwum Krajowej Komisji NSZZ "Solidarność" Brzostowski H., 2015, List.

Butrym S., 2015, Relacja.

Cenckiewicz S., 2003, Pomorze Gdańskie i Kujawy [w:] Stan wojenny 1981-1983, red. A. Dudek, Warszawa: IPN.

19 Jak można przeczytać w charakterystyce kapitana Helmana, „ewentualny ich wyjazd z Polski do Berlina Zachodniego nie przyniesie większego uszczerbku gospodarce narodowej". 
Cenckiewicz S., 2005, Od "Klanu” do "Renesansu”. Operacje Służby Bezpieczeństwa wobec kierownictwa "Solidarności" w latach 1980-1982 [w:] S. Cenckiewicz, Oczami bezpieki. Szkice i materiały z dziejów aparatu bezpieczeństwa PRL, Kraków: Arcana.

Friszke A., 2014, Rewolucja Solidarności 1980-1981, Kraków: Znak Horyzont.

Gargol S., 1981, Pismo szefa Biura Interwencji MKZ NSZZ "Solidarność” w Słupsku S. Gargola, Gdańsk: Archiwum Krajowej Komisji NSZZ „Solidarność", k. 13024-13021.

Gierałtowski J., 1982, Szyfrogram dot. uchylenia decyzji o internowaniu, k. 200, Gdańsk: Instytut Pamięci Narodowej. Oddziałowe Biuro Udostępniania i Archiwizacji Dokumentów.

Grymbowski M. 2013, Relacja z 23.11.2013.

Hałagida I., 2010a, NSZZ „Solidarność" Regionu Słupskiego (1980-1990), t. 1: Szkice do monografii, Gdańsk: IPN.

Hałagida I., 2010b, Służba Bezpieczeństwa wobec NSZZ „Solidarność” w Słupsku, „Pamięć i Sprawiedliwość", 2.

Hałagida I., 2011a, NSZZ „Solidarność" Regionu Słupskiego (1980-1990), t. 2: Dokumenty Komitetu Wojewódzkiego PZPR i Służby Bezpieczeństwa, Gdańsk: IPN.

Hałagida I., 2011b, Województwo słupskie [w:] „Trzynastego grudnia roku pamiętnego....". Internowani w stanie wojennym z powodów politycznych z województw bydgoskiego, elbląskiego, gdańskiego, słupskiego, toruńskiego i włocławskiego, red. I. Hałagida, Bydgoszcz-Gdańsk: IPN.

Hałagida I., 2012, Rozpracowanie Kryptonim "Podregion" - wewnątrzresortowe omówienie działań Służby Bezpieczeństwa przeciwko podziemnym strukturom NSZZ „Solidarność" w Lęborku (1982-1983), "Słupskie Studia Historyczne", nr 18.

Hałagida I., 2016, http://www.encysol.pl/wiki/Kazimierz_Duda [dostęp: 27.06.2017].

Harat B., 2013, Relacja.

Heldt E., 2013, Relacja.

Heldt E., 2014, Notatka z rozmowy telefonicznej z E. Heldtem.

Helman K., 1984, Wniosek o podjęcie decyzji pozytywnej na wyjazd stały do Berlina Zachodniego, Gdańsk, Instytut Pamięci Narodowej. Oddziałowe Biuro Udostępniania i Archiwizacji Dokumentów, k. 24.

Informacja dotycząca wniosków i postulatów, wysuniętych na spotkaniach załóg zakładów pracy miasta i gminy Miastko w dniach 22.08.-5.09.1980, 1980, Słupsk: Archiwum Państwowe, k. 52-55.

Informacja operacyjna dot. ośrodka dla internowanych w Strzebielinku, 1982, Gdańsk: Instytut Pamięci Narodowej. Oddziałowe Biuro Udostępniania i Archiwizacji Dokumentów, k. 70.

Informacja operacyjna dotycząca posiedzenia plenum MKZ w Słupsku, 1981, Gdańsk: Instytut Pamięci Narodowej. Oddziałowe Biuro Udostępniania i Archiwizacji Dokumentów, k. 135.

Informacje dotyczące zebrania MKZ NSZZ „Solidarność” W Słupsku, odbytego dnia 12.03.1981, 1981, Gdańsk: Instytut Pamięci Narodowej. Oddziałowe Biuro Udostępniania i Archiwizacji Dokumentów, k. 58.

Kamiński Ł., 2002, PZPR wobec "Solidarności" - pierwsze tygodnie, „Biuletyn IPN”, nr 12.

Karwowski B., 1980, Pismo dyrektora B. Karwowskiego ws. urlopu dla W. Stojaka, k. 5186, Gdańsk: Archiwum Krajowej Komisji NSZZ "Solidarność".

Kontrwywiadowcza charakterystyka terenu działalności RUSW w Miastku, 1984, Gdańsk: Instytut Pamięci Narodowej. Oddziałowe Biuro Udostępniania i Archiwizacji Dokumentów, k. 149. 
Kozłowski T., 2013, PZPR a Solidarność 1980-1981 [w:] PZPR a Solidarność 1980-1981. Tajne dokumenty Biura Politycznego, Warszawa: IPN.

Król T., 2013, Relacja.

Kwiatkowski S., 1981, Szyfrogram ppłk S. Kwiatkowskiego do naczelnika Wydziału I Departamentu III/a MSW w Warszawie, Gdańsk: Instytut Pamięci Narodowej. Oddziałowe Biuro Udostępniania i Archiwizacji Dokumentów, k. 81.

Ławer K. i P., 2015, Relacja.

Medel J., 2015, Relacja.

Muchowski B., 2015, Relacja.

Mur J. (Drzycimski A., Kinaszewski J.), 1989, Dziennik internowanego (grudzień 1981-grudzień 1982), Gdańsk-Warszawa: Modem, Polski Dom Wydawniczy.

Nakaz zatrzymania i doprowadzenia W. Stojaka, 1981, Gdańsk: Instytut Pamięci Narodowej. Oddziałowe Biuro Udostępniania i Archiwizacji Dokumentów, k. 2.

Notatka służbowa dot. Władysława Stojaka, 1981, Gdańsk: Instytut Pamięci Narodowej. Oddziałowe Biuro Udostępniania i Archiwizacji Dokumentów, k. 62.

Okoniewska B., 1998, Organizacja życia społecznego i politycznego po zakończeniu działań wojennych [w:] Historia Bytowa, red. Z. Szultka, Bytów: Wydział Oświaty, Kultury, Sportu i Turystyki Urzędu Miejskiego.

Osiński K., Rybarczyk P., 2013a, Kryzys bydgoski. Przyczyny, przebieg, konsekwencje, t. 1: Monografia, Bydgoszcz-Gdańsk-Warszawa: IPN.

Osiński K., Rybarczyk P., 2013b, Kryzys bydgoski. Przyczyny, przebieg, konsekwencje, t. 2: Dokumenty, Bydgoszcz-Gdańsk-Warszawa: IPN.

Paczkowski A., 2002, Droga do „mniejszego zła”. Strategia i taktyka obozu władzy lipiec 1980-styczeń 1982, Kraków: Wydawnictwo Literackie.

Paczkowski A., 2006, Wojna polsko-jaruzelska. Stan wojenny w Polsce 13 XII 1981-22 VII 1983, Warszawa: Prószyński i Ska.

Pierwszy krok za nami, 1981, „Zbliżenia”, nr 21, s. 6.

Pismo do Zarządu Gospodarki Terenowej w Miastku, 1981, Gdańsk: Archiwum Krajowej Komisji NSZZ „Solidarność", k. 5148-5150.

Połeć P., 1981a, Motywy, "Solidarność Słupska”, nr 13/34, s. 1.

Połeć P., 1981b, Z obrad Woj. Konferencji Partyjnej, Gdańsk: Archiwum Krajowej Komisji NSZZ „Solidarność", k. 13534-13535.

Postulaty zakładów pracy, 1980, Informacja dotycząca wniosków i postulatów, wysuniętych na spotkaniach załóg zakładów pracy miasta i gminy Miastko w dniach 22.08.-5.09.1980, Słupsk: Archiwum Państwowe, k. 52-55.

Protokół nr 9/81 z posiedzenia Egzekutywy Komitetu Miejsko-Gminnego PZPR w Miastku, 1981, Słupsk: Archiwum Państwowe, k. 52.

Protokół nr 19/81 z posiedzenia Egzekutywy Komitetu Miejsko-Gminnego PZPR w Miastku, 1981, Słupsk: Archiwum Państwowe, k. 114-115.

Protokół nr 1/82 z posiedzenia Egzekutywy Komitetu Miejsko-Gminnego PZPR w Miastku, 1982, Słupsk: Archiwum Państwowe, k. 2.

Protokół z III Konferencji Sprawozdawczo-Wyborczej Komitetu Miejsko-Gminnego PZPR w Miastku, 1981, Słupsk: Archiwum Państwowe, k. 1-59. 
Protokół z narady w urzędzie miasta i gminy, 1981, Gdańsk: Archiwum Krajowej Komisji NSZZ "Solidarność", k. 4878-4882.

Protokół z narady z siostrami pogotowia PCK z udziałem NSZZ „Solidarność” w Miastku, 1980, Gdańsk: Archiwum Krajowej Komisji NSZZ „Solidarność”, k. 1627.

Protokół z pierwszego plenarnego posiedzenia Komitetu Powiatowego PZPR w Miastku, 1975, Koszalin, Archiwum Państwowe, [b.p.].

Protokół z przeprowadzonej kontroli w POP przy Zakładzie Produkcji Leśnej „Las", 1977, Komisja Kontroli Partyjnej, Słupsk: Archiwum Państwowe, k. 105.

Rodź H., 2015, Relacja.

Skarga do NIK, 1981, Gdańsk: Archiwum Krajowej Komisji NSZZ „Solidarność”, k. 13005.

Sobolewski J., 2015, Relacja.

Sobolewski Z., 2000, NSZZ „Solidarność" w przedsiębiorstwie Polskie Koleje Państwowe 1980-2000, t. 1, Gdańsk: Sekcja Krajowa Kolejarzy NSZZ Solidarność.

"Solidarność". Biuletyn OKO NSZZ „Solidarność" Słupska, 1982.

"Solidarność Słupska”, 1981a, nr 6.

„Solidarność Słupska”, 1981b, nr 9.

Stan wojenny w dokumentach władz PRL (1980-1983), 2001, wyb., wstęp i oprac. B. Kopka, G. Majchrzak, Warszawa: IPN.

Stojak E., 1982, Prośba E. Stojak do wojewody słupskiego C. Przewoźnika, Gdańsk, Instytut Pamięci Narodowej. Oddziałowe Biuro Udostępniania i Archiwizacji Dokumentów, k. 65.

Stojak W., 1980, Teleks W. Stojaka do przewodniczącego Komisji Robotniczej NSZZ „Solidarność” przy RPGKiM, Gdańsk: Archiwum Krajowej Komisji NSZZ „Solidarność”, k. 5155.

Stojak W., 1981, Zwolnienie z pracy, zbiory W. Stojaka.

Stojak W., 1982a, Kwestionariusz paszportowy W. Stojaka, Gdańsk, Instytut Pamięci Narodowej. Oddziałowe Biuro Udostępniania i Archiwizacji Dokumentów, k. 1-24.

Stojak W., 1982b, Odwołanie W. Stojaka od decyzji wypowiedzenia z pracy, Zbiory W. Stojaka.

Stojak W., 1983, Kwestionariusz paszportowy W. Stojaka, Gdańsk, Instytut Pamięci Narodowej. Oddziałowe Biuro Udostępniania i Archiwizacji Dokumentów, k. 20.

Stojak W., 2014a, Relacja.

Stojak W., 2014b, List.

Stola D., 2010, Kraj bez wyjścia? Migracje z Polski 1949-1989, Warszawa.

Szymak S., 1981, Szyfrogram ppłk S. Szymaka do kierownika komisariatu MO w Miastku, Gdańsk, Instytut Pamięci Narodowej. Oddziałowe Biuro Udostępniania i Archiwizacji Dokumentów, k. 138.

Szymak S., 1982, Pismo ppłk. S. Szymaka do komendanta obozu w Strzebielinku, k. 212, Gdańsk, Instytut Pamięci Narodowej. Oddziałowe Biuro Udostępniania i Archiwizacji.

Śledź S. 2015, Relacja.

Tajne dokumenty Biura Politycznego Biura Politycznego. PZPR a „Solidarność”, 1992, Londyn: Aneks.

Teleks nr 185 dot. sytuacji w ruchu związkowym w woj. słupskim, 1980, KW, Słupsk: Archiwum Państwowe, k. 80.

Teleks nr 177, 1981, KW, Słupsk: Archiwum Państwowe, k. 117.

Teleks nr 291, 1981, KW, Słupsk: Archiwum Państwowe, k. 9. 
Turek W., 2016, Ośrodek Odosobnienia dla Internowanych w Strzebielinku, http://www.encyklopediasolidarnosci.pl/wiki/index.php?title=T01987_O\%C5\%9Brodek_Odosobnienia_w_Strzebielinku [dostęp: 26.05.2016].

TW Roman 1981, Meldunek TW Romana, Gdańsk, Instytut Pamięci Narodowej. Oddziałowe Biuro Udostępniania i Archiwizacji Dokumentów, k. 149.

TW Sąsiad 1981, Raport z odbytego spotkania z TW Sąsiad, Gdańsk, Instytut Pamięci Narodowej. Oddziałowe Biuro Udostępniania i Archiwizacji Dokumentów, k. 148.

TW Urban 1982, Raport z odbytego spotkania z TW Urban, Gdańsk, Instytut Pamięci Narodowej. Oddziałowe Biuro Udostępniania i Archiwizacji Dokumentów, k. 219.

Tygodnik „Solidarność”, 1981, nr 26.

Uchwała Komitetu Wojewódzkiego PZPR w Słupsku w sprawie zwołania wojewódzkiej konferencji wyborczej, 1981, KW PZPR, Słupsk: Archiwum Państwowe, k. 14.

Walne Zebranie Delegatów NSZZ „Solidarność" Podregionu Miastko 1981, Gdańsk, Archiwum Komisji Krajowej NSZZ "Solidarność", k. 4672-4863.

Wniosek Komitetu Obchodów 1, 3, 9 maja przy MKK NSZZ "Solidarność" w Miastku o zabezpieczenie mszy św., 1981, Gdańsk: Archiwum Krajowej Komisji NSZZ „Solidarność", k. 5146.

Wyciąg z protokołu z plenarnego posiedzenia KW w Słupsku, 1981, KW PZPR, Słupsk: Archiwum Państwowe, k. 138.

Żmudzki J., 2014, Relacja. 


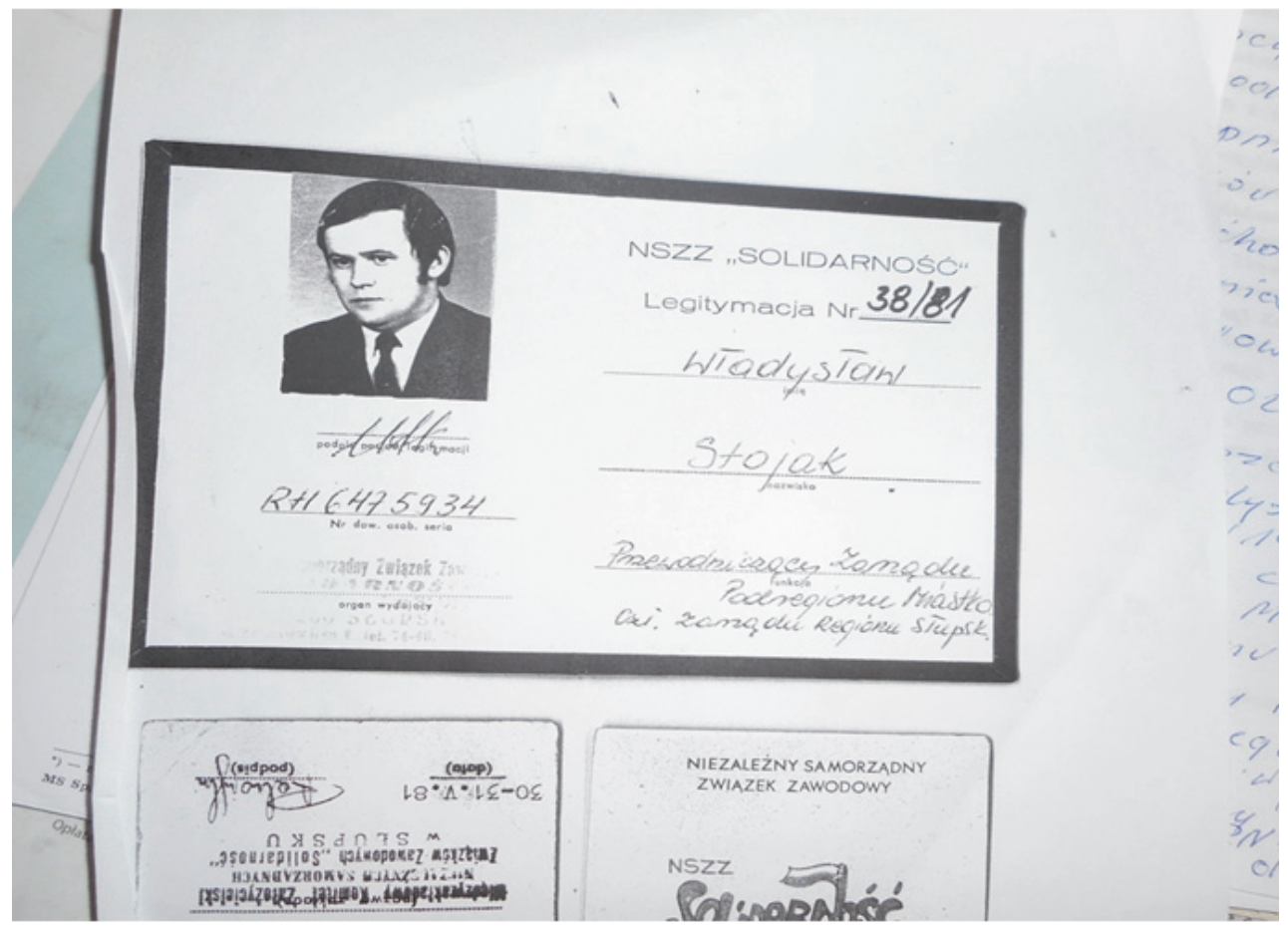

Fot. 1. Władysław Stojak w latach sześćdziesiątych

Źródło: ze zbiorów Władysława Stojaka.

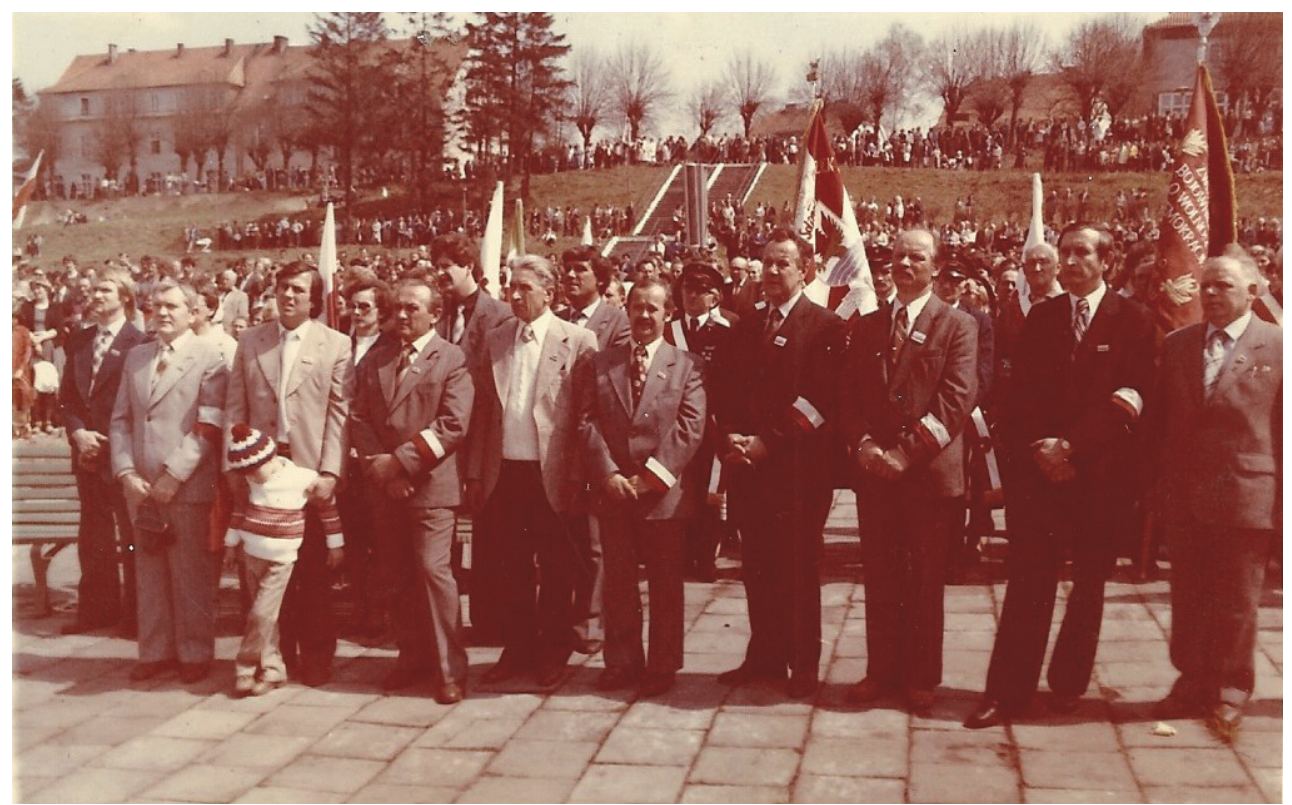

Fot. 2. Działacze MKK NSZZ „Solidarność" w Miastku podczas mszy 9 maja 1981 roku Źródło: ze zbiorów Brygidy Harat. 


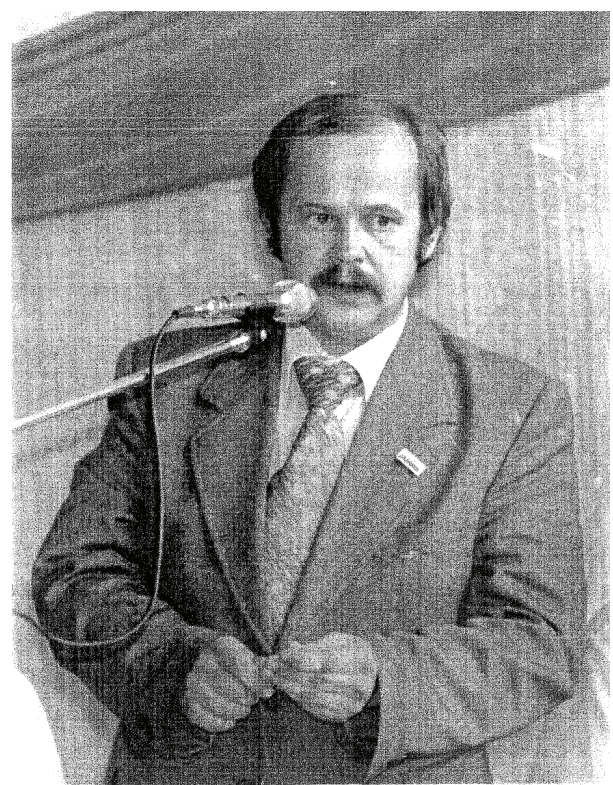

Fot. 3. Władysław Stojak podczas I

Walnego Zebrania Delegatów Podregionu

Miastko, 27 czerwca 1981

Źródło: ze zbiorów Władysława Stojaka.

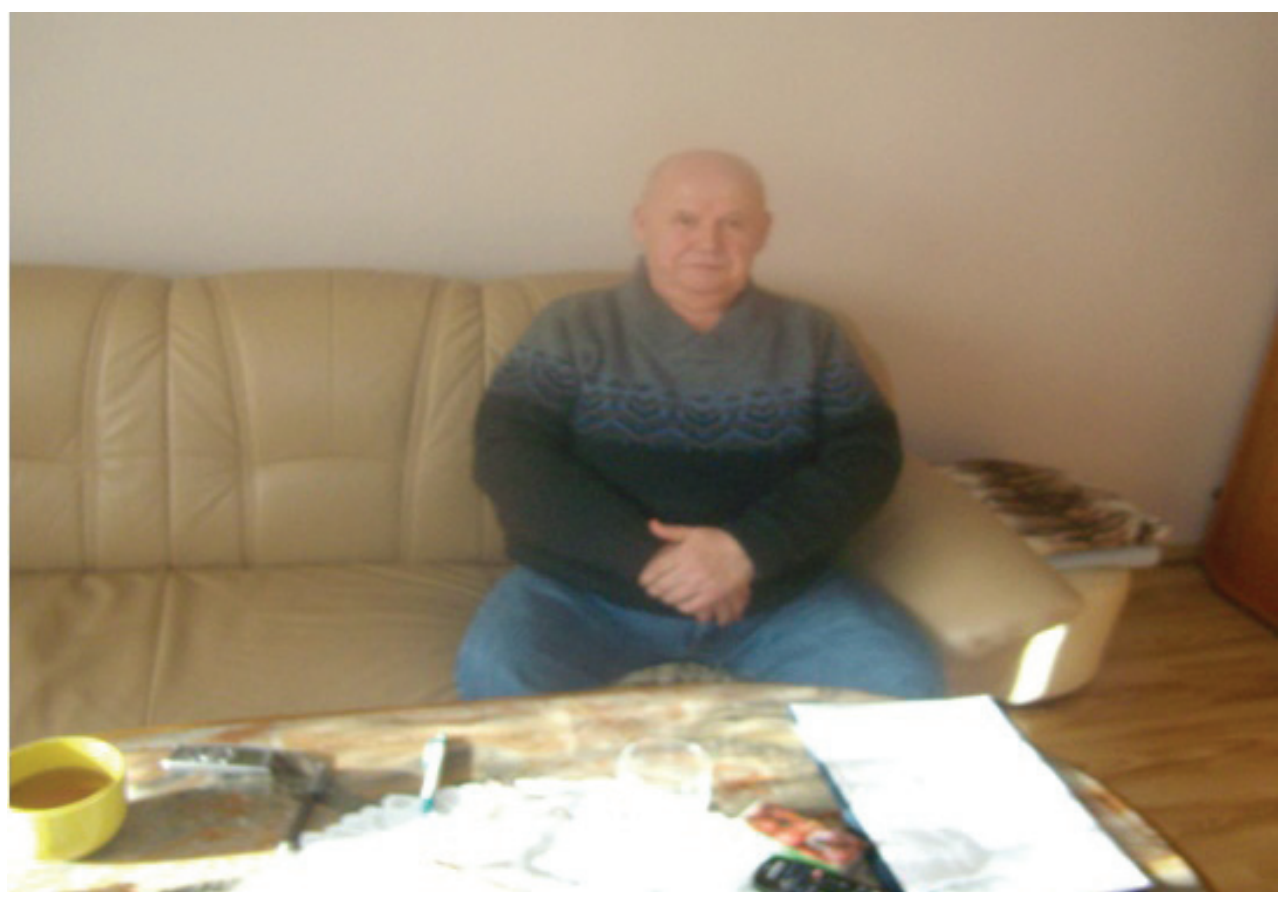

Fot. 4. Władysław Stojak, 12 llutego 2014

Źródło: ze zbiorów Władysława Stojaka. 